\title{
THE PROBLEMS OF COMPUTATION OF COMBINED PLATES WITH PIECEWISE VARIABLE THICKNESS. SOLUTIONS IN ORTHOGONAL POLYNOMIALS
}

\author{
Elena B. Koreneva ${ }^{1}$, Valery R. Grosman ${ }^{2}$ \\ ${ }^{1}$ Moscow Higher Combined-Arms Command Academy, Moscow, RUSSIA \\ ${ }^{2}$ Moscow State Academy for River Transport, Moscow, RUSSIA
}

\begin{abstract}
The work is devoted to the analytical simulation of the combined plates calculation. The mentioned plates have the circular form and they consist of separate parts with different laws of thickness variation. These sections may be made from the same or from different materials. The material can be homogeneous or nonhomogeneous, isotropic or anisotropic. In the places of the separate sections conjugation the construction's thickness can be continuous or discontinuous. The construction under study is subjected to an action of bending loads. Below the analytical method for the similar constructions' computation is suggested. This method is based on the use of the theory of the special functions, in particular, Lagerr's orthogonal polynomials.
\end{abstract}

Keywords: combined constructions, piecewise variable thickness, Lagerr's orthogonal polynomials.

\section{ПРОБЛЕМЫ РАСЧЕТА КОМБИНИРОВАННЫХ ПЛАСТИН КУСОЧНО-ПЕРЕМЕННОЙ ТОЛЩИНЫ. РЕШЕНИЯ В КЛАССИЧЕСКИХ ОРТОГОНАЛЬНЫХ МНОГОЧЛЕНАХ}

\author{
Е.Б. Коренева ${ }^{1}$, В.Р. Гросман ${ }^{2}$ \\ ${ }^{1}$ Московское высшее общевойсковое командное орденов Жукова, Ленина и Октябрьской Революции \\ Краснознаменное училище, г. Москва, РОССИЯ \\ ${ }^{2}$ Московская государственная академия водного транспорта, г. Москва, РОССИЯ
}

\begin{abstract}
Аннотация: Работа посвящена аналитическому моделированию проблем расчета комбинированных пластин, имеющих в плане круговую форму и состоящих из отдельных участков, в которых толщина изменяется по различным законам. Эти отдельные участки могут быть сделаны как из одного и того же, так и из различных материалов, которые могут обладать свойствами однородности или неоднородности; быть изотропными или анизотропными. В местах стыков отдельных участков толщина конструкции может быть или непрерывной, или иметь разрыв непрерывности. Изучаемые конструкции работают на изгиб. Ниже предлагается аналитическая методика расчета подобных конструкций, связанная с использованием классических ортогональных многочленов, в частности, многочленов Лагерра.
\end{abstract}

Ключевые слова: комбинированные конструкции, кусочно-переменная толщина, многочлены Лагерра.

\section{INTRODUCTION}

The plates having a circular form and consisting of two or a few parts with various laws of thickness variation are under consideration. Such plates occur as constructive elements in modern buildings and structures. Their separate parts may be made from the same or different materials. These materials can be homogeneous or inhomogeneous, isotropic or anisotropic. In the places of the sections conjugation the plate's thickness can be continuous or it has a discontinuity. The analytical methods of the such construction computation, specifically connected with the theory of the special functions, are not yet developed. The work [1] is to be mentioned. In this work the foundation slab, resting on an elastic subgrade, was under consideration. The plate's inner part has variable thickness, the outer part has the constant thickness. The solutions were received in terms of Bessel functions. The present work considers the bending of the combined plate with the piecewise variable thickness. The solutions are obtained in 
the closed form in terms of the Lagerr's orthogonal polynomials and the confluent functions.

\section{THE STATEMENT OF THE PROBLEM}

The works, in which to the circular plates of variable and constant thickness analysis the theory of the special functions is used, are known in literature, for example [2], [3], [4].

Let us go to the consideration of the combined plates which were described above (Fig.1).

The differential equation, describing the symmetric bending of the circular orthotropic plate with the varying thickness, has the form [3], [4]:

$$
\begin{gathered}
r^{2} \frac{\partial^{2} \vartheta}{\partial r^{2}}+r\left(1+\frac{r}{D} \frac{d D}{d r}\right) \frac{d \vartheta}{d r}+\left(\frac{\sigma r}{D} \frac{d D}{d r}-n^{2}\right) \vartheta+ \\
+\frac{r}{D n_{2}}\left(\int q_{Z} r d r-C\right)=0,
\end{gathered}
$$

here $\vartheta=-\frac{d w}{d r}, \sigma$ is the Poisson's ratio, the parameters $n^{2}=n_{1} n_{2}$ are determined by the following expressions:

$$
E_{r}=\frac{E}{n_{2}}, E_{\theta}=E n_{2}, \sigma_{r}=\frac{\sigma}{n^{2}}, \sigma_{\theta}=\sigma .
$$

For isotropic plate $n_{1}=n_{2}=1$.

Let us write:

$$
-\int q_{z} r d r+C=Q_{r} r
$$

The stresses in the orthotropic circular plate of variable thickness are determined from the following expressions:

$$
\begin{gathered}
M_{r}=D n_{2}\left(\frac{d \vartheta}{d r}+\frac{\sigma}{r} \vartheta\right), \\
Q_{r}=D n_{2}\left(\frac{d^{2} \vartheta}{d r^{2}}+\frac{1}{r} \frac{d \vartheta}{d r}-\frac{n^{2}}{r^{2}} \vartheta\right)+ \\
+\frac{d D}{d r} n_{2}\left(\frac{d \vartheta}{d r}+\frac{\sigma}{r} \vartheta\right) .
\end{gathered}
$$

Introducing the independent argument:

$$
x=\left(\frac{r}{r_{0}}\right)^{\alpha_{0}},
$$

where $\alpha_{0}, r_{0}-$ are the constants.

Substituting (5) into (1) we get, assuming $q_{Z}=0$ :

$$
\begin{gathered}
\frac{d^{2} \vartheta}{d x^{2}}+\left(\frac{1}{x}+\frac{1}{D} \frac{d D}{d x}\right) \frac{d \vartheta}{d x}+ \\
+\frac{1}{\alpha_{0} x}\left(\frac{\sigma}{D} \frac{d D}{d x}-\frac{n^{2}}{\alpha_{0} x}\right) \vartheta-\frac{C r_{0} x}{D n_{2} \alpha_{0}^{2}}=0 .
\end{gathered}
$$

We consider the cases of symmetric bending of orthotropic circular plates of variable thickness which allow receiving the solution in terms of Lagerr's orthogonal polynomials. Let us write the differential equation for Lagerr's polynomials [5]:

$$
y^{\prime \prime}+\frac{\alpha+1-x}{x} y^{\prime}+\frac{m}{x} y=0 \text {. }
$$

As the result we receive that the sought solution occur for the following law of flexural rigidity variation:

$$
D=D_{0} x^{\alpha} e^{-x}
$$

where

$$
\alpha=-m n^{2} / \sigma^{2}, \alpha_{0}=-\sigma / m .
$$

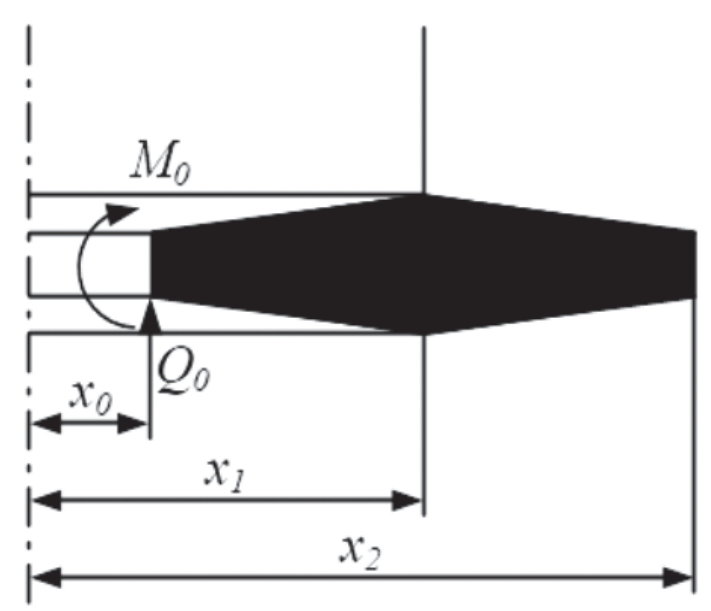

Figure 1. The combined plates with the piecewise variable thickness 
The general solution of the homogeneous equation, corresponding to (6), is

$$
\vartheta=A L_{m}^{\alpha}(x)+B x_{1}^{-\alpha} F_{1}(-m-\alpha ; 1-\alpha ; x) .
$$

In the similar way we can get the solutions in terms of different polynomials, for example in Chebyshev or Hermite polynomials. However these laws have more restricted domain of definition than (8).

The following law of thickness variation, corresponding to the flexural rigidity (8), is

$$
h=h_{0} x^{\alpha / 3} e^{-x / 3} .
$$

The set of curves, corresponding to the profiles (11), can be built. In this case it must be taken into account that the Poisson's ratio $\sigma$ is limited (9).

\section{THE COMBINED PLATE}

The combined plate with piecewise thickness variation is under consideration. The proposed method will be shown on the example of the combined plate consisting of two parts. However the suggested method can be applied for combined plates, consisting of several parts, analysis. Let us assume that in our example the plate's thickness is continuous in the place of joint (Fig.2).

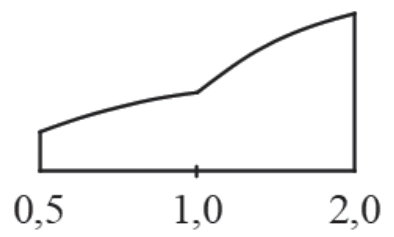

Figure 2. The combined plate consisting of two parts

The special auxiliary functions are introduced for the realization of the separate parts joint and for consideration of the action of discontinuous loads, distributed along the circles non-coinciding with the plate's contour.

First we shall write the wronskian for the solutions (10):

$$
W(x)=\left(\begin{array}{c}
m+\alpha \\
m
\end{array}\right) \alpha x^{-\alpha-1} e^{-x} .
$$

Next the Cauchy functions for the solutions (10) $Y_{1}\left(x_{1} ; x\right), Y_{2}\left(x_{1} ; x\right)$ are to be obtained. The indicated functions are defined by the expressions:

$$
\begin{gathered}
Y_{1}\left(x_{1} ; x\right)=\left(\begin{array}{c}
m+\alpha \\
m
\end{array}\right)^{-1} \alpha^{-1} e^{-x_{1}} x^{\alpha+1} \times \\
\times\left\{\left[\alpha x_{1}^{-\alpha-1}{ }_{1} F_{1}\left(-m-\alpha ; 1-\alpha ; x_{1}\right)+x_{1}^{-\alpha} \times\right.\right. \\
\left.\times \frac{m+\alpha}{1-\alpha}{ }_{1} F_{1}\left(-m-\alpha+1 ; 2-\alpha ; x_{1}\right)\right] L_{m}^{\alpha}(x)- \\
-\left[\frac{m}{x_{1}} L_{m}^{\alpha}\left(x_{1}\right)-\frac{m+\alpha}{x_{1}} L_{m-1}^{\alpha}\left(x_{1}\right)\right] \times \\
\left.\quad \times x^{-\alpha}{ }_{1} F_{1}(-m-\alpha ; 1-\alpha ; x)\right\}, \\
Y_{2}\left(x_{1} ; x\right)=\left(\begin{array}{c}
m+\alpha \\
m
\end{array}\right)^{-1} \alpha^{-1} e^{-x_{1}} x_{1}^{\alpha+1} \times \\
\times\left\{-L_{m}^{\alpha}\left(x_{1}\right) x^{\alpha}{ }_{1} F_{1}(-m-\alpha ; 1-\alpha ; x)+\right. \\
\left.+x_{11}^{\alpha}{ }_{1} F_{1}\left(-m-\alpha ; 1-\alpha ; x_{1}\right) L_{m}^{\alpha}(x)\right\}
\end{gathered}
$$

Further the auxiliary functions $\vartheta_{i}\left(x_{1} ; x\right)(i=1,2,3)$, which properties are described in [4], introduced into consideration are sought in the form:

$$
\begin{aligned}
\vartheta_{i}\left(x_{1} ; x\right)=A_{i 1} & Y_{1}\left(x_{1} ; x\right)+A_{i 2} Y_{2}\left(x_{1} ; x\right)+ \\
& +A_{i 3} \vartheta_{C}(x),
\end{aligned}
$$

here $\vartheta_{C}$ is the particular solution of the inhomogeneous equation (6). In our case

$$
\vartheta_{C}(x)=\frac{C r_{0}}{D_{0}(1-\sigma)} e^{-x}\left(1-\frac{1}{\sigma x}\right) .
$$

As a result we receive:

$$
\begin{gathered}
\vartheta_{1}\left(x_{1} ; x\right)=\left[1-B_{1} \vartheta_{C}\left(x_{1}\right)\right] Y_{1}\left(x_{1} ; x\right)+ \\
+\left[\frac{\sigma}{\alpha_{0} x_{1}}+B_{1} \vartheta_{C}^{\prime}\left(x_{1}\right)\right] Y_{2}\left(x_{1} ; x\right)+B_{1} \vartheta_{C}(x), \\
\vartheta_{2}\left(x_{1} ; x\right)=-B_{2} \vartheta_{C}\left(x_{1}\right) Y_{1}\left(x_{1} ; x\right)- \\
-\left[B_{2} \vartheta_{C}{ }^{\prime}\left(x_{1}\right)-\frac{r_{0}}{\alpha_{0} D\left(x_{1}\right)} x_{1}^{\frac{1}{\alpha_{0}}-1}\right] Y_{2}\left(x_{1} ; x\right)+ \\
+B_{2} \vartheta_{C}(x), \\
\vartheta_{3}\left(x_{1} ; x\right)=B_{3}\left\{-\vartheta_{C}\left(x_{1}\right) Y_{1}\left(x_{1} ; x\right)-\right. \\
\left.-\vartheta_{C}\left(x_{1}\right) Y_{2}\left(x_{1} ; x\right)+\vartheta_{C}(x)\right\},
\end{gathered}
$$


where

$$
\begin{aligned}
& B_{1}=\frac{1}{\vartheta_{C}{ }^{\prime}\left(x_{1}\right)}\left[-Y_{1}^{\prime \prime}\left(x_{1} ; x_{1}\right)+\frac{\sigma}{\alpha_{0} x_{1}} Y_{2}^{\prime \prime}\left(x_{1} ; x_{1}\right)+\right. \\
& \left.+\frac{1}{\alpha_{0} x_{1}^{2}}\left(\sigma+\frac{1}{\alpha_{0}}\right)\right], \\
& B_{2}=-\frac{r_{0}}{\alpha_{0} D\left(x_{1}\right) \vartheta_{C}{ }^{\prime}\left(x_{1}\right)} x_{1}^{\frac{1}{\alpha_{0}}-1} \times \\
& \times\left[Y_{1}^{\prime \prime}\left(x_{1} ; x_{1}\right)+\frac{1}{x_{1}} Y_{2}{ }^{\prime \prime}\left(x_{1} ; x_{1}\right)+\frac{1}{D\left(x_{1}\right)} \frac{d D\left(x_{1}\right)}{d x}\right], \\
& B_{3}=\frac{r_{0}^{2}}{\alpha_{0}^{2}} x_{1}^{\frac{2}{\alpha_{0}}-2} \frac{1}{D\left(x_{1}\right) \vartheta_{C}{ }^{\prime}\left(x_{1}\right)} .
\end{aligned}
$$

It should be noted that in consideration of the combined plates with the piecewise variable rigidity the Cauchy functions and the auxiliary functions $\vartheta$ are different for separate sections. It is valid since the each part has its law of thickness variation $h(x)$ and its own parameters' values. Therefore we introduce the appropriate notation $Y_{1}^{(1)}, Y_{2}^{(1)}, Y_{1}^{(2)}, Y_{2}^{(2)}$ and $\vartheta_{i}^{(1)}, \vartheta_{i}^{(2)}$. Let that the combined plate, shown on the Fig.2, is made from the isotropic material that is $n^{2}=1$. We assume that the Poisson's ratio is $\sigma=1 / 3$. The plate's thickness in the first section when $0,5 \leq x \leq 1,0$ is approximated by the formula (11) when $m=2$. On the second section $1,0 \leq x \leq 2,0$ the plate's thickness is approximated by the same formula (11) when the parameter $m=1$. The plate's thickness in the place of the sections' joint $x=x_{2}=1,0$ is continuous.

We denote as $\vartheta_{0}, M_{0}, Q_{0}$ correspondingly the angle of rotation, the moment and the force on the inner contour of the plate. The expression for the angles of rotation for the first section $x_{1} \leq x \leq x_{2}$ is

$$
\begin{gathered}
\vartheta=\vartheta_{I}=\vartheta_{0} \vartheta_{1}^{(1)}\left(x_{0} ; x\right)+M_{0} r_{0} \vartheta_{2}^{(1)}\left(x_{0} ; x\right)+ \\
+Q_{0} r_{0}^{2} \vartheta_{3}^{(1)}\left(x_{0} ; x\right) .
\end{gathered}
$$

For the second section when $x_{2} \leq x \leq x_{3}$ the angles of rotation are determined by the formula

$$
\begin{gathered}
\vartheta=\vartheta_{\mathrm{II}}=\vartheta_{1}\left(x_{1}\right) \vartheta_{1}^{(2)}\left(x_{1} ; x\right)+ \\
+M_{1}\left(x_{1}\right) r_{0} \vartheta_{2}^{(2)}\left(x_{1} ; x\right)+Q_{1}\left(x_{1}\right) r_{0}^{2} \vartheta_{3}^{(2)}\left(x_{1} ; x\right),
\end{gathered}
$$

where $\vartheta_{1}\left(x_{1}\right), M_{1}\left(x_{1}\right), Q_{1}\left(x_{1}\right)$ are received by the use of the formulae (17) and (4).

The expressions for the deflections can be also received. The proposed method can be successfully applied for the combined plates with the piecewise thickness variation consisting of several parts.

\section{THE CONCLUSION}

The work develops the analytical method of the combined plates with the piecewise variable thickness computation. The constructions under study have the circular shape and consist of several parts with different laws of thickness variation. These parts may be made from the same or from the different materials which can be isotropic or orthotropic. In the places of the separate sections joint the thickness can be continuous or discontinuous. For the receiving of the solutions the theory of the special functions is used. The solutions are obtained in closed form and expressed in terms of Lagerr's polynomials and the confluent hypergeometric functions.

\section{REFERENCES}

1. Koreneva E.B. Usovershenstvovannyi Raschet Kombinirovannoj Fundamentnoj Plity Specialnogo Sooruzhenija. (Refined Analysis of the Combined Foundation Plate of the Special Building) // Sb. Trudov Natsionalnoj Nauchno-Tehnicheskoj Konferentsii s Inostrannym Uchastiem «Mehanika Gruntov v Geotehnike i Fundamentostrojenii», g. Novocherkassk, Rostovskaja Obl., 29-31 Maja, 2018, s. 193-197 (in Russian).

2. Korenev B.G. Nekotorye Zadachi Teorii Uprugosti i Teploprovodnosti, Reshajemye v Besselevyh Funktzijah. (The Certain Problems of the Theory of Elasticity and Heat Conductivity Solving in Terms of Bessel Functions). - M., Fizmatgiz, 1960, 458 s. (in Russian).

3. Kovalenko A.D. Izbrannye Trudy. (The Selected Works). - Kiev, Naukova Dumka, 1976, 762 s. (in Russian).

4. Koreneva E.B. Analiticheskije Metody Rascheta Plastin Peremennoj Tolshiny i ih Prakticheskije Prilozhenija. (Analylical Methods of Plates of Variable Thickness Analysis and Their Practical Application). - M., ASV, 2009, 238 s. (in Russian).

5. Abramovits M., Stigan I. Spravochnik po Specialnym Funktsijam. (Handbook for Special Functions). - M., Nauka, 1979, 820 s. (in Russian). 


\section{СПИСОК ЛИТЕРАТУРЫ}

1. Коренева Е.Б. Усовершенствованный расчет комбинированной фундаментной плиты специального сооружения // Сборник трудов национальной научно-технической конференции с иностранным участием «Механика грунтов в геотехнике и фундаментостроении», г. Новочеркасск, Ростовская обл., 29-31 мая 2018 г., c.193-197.
2. Коренев Б.Г. Некоторые задачи теории упругости и теплопроводности, решаемые в бесселевых функциях. - М.: Физматгиз, 1960. - 458 с.

3. Коваленко А.Д. Избранные труды. - Киев: Наукова думка, 1976. - 762 с.

4. Коренева Е.Б. Аналитические методы расчета пластин переменной толщины и их практические приложения. - М.: АСВ, 2009. - 240 с.

5. Абрамовиц М., Стиган И. Справочник по специальным функциям. - М.: Наука, 1979. - 820 с.

Elena B. Koreneva, Dr.Sc., professor, Moscow Higher Combined-Arms Command Academy, ul. Golovacheva, 2, 109380, Moscow, Russia, tel.: +7(499)175-82-45.

Коренева Елена Борисовна, доктор технических наук, профессор, Московское высшее общевойсковое командное орденов Жукова, Ленина и Октябрьской Революции Краснознаменное училище, 109380, Россия, г. Москва, ул. Головачева, д.2, тел.: +7(499)175-82-45, e-mail: elena.koreneva2010@yandex.ru.

Valery R. Grosman, Moscow State Academy for River Transport, associate professor, Novodanilovskaya nab., 2, k.1, 117105, Moscow, Russia, tel.: +7(499)618-52-56.

Гросман Валерий Романович, МГАВТ - филиал ФГБОУ ВО «ГУМРФ имени адмирала С.О. Макарова», старший преподаватель, 117105, Россия, г. Москва, Новоданиловская наб., д.2, корп.1, тел.: +7(499)618-52-56, e-mail: elena.koreneva2010@ yandex.ru. 